\title{
THE DEONTOUTILITARIANIST MANIFESTO
}

\author{
O MANIFESTO DEONTOUTILITARISTA
}

\author{
CINARA NAHRA ${ }^{1}$
}

(UFRN, Brasil)

\begin{abstract}
The purpose of this paper is to propose a set of 11 moral rules that are based on a combination of Kant's categorical imperative, Mill's Greatest Happiness and Mill's Principle of Harm. In short the 11 rules of deontoutilitarianism are: 1) Human Beings have the duty of a) to preserve themselves and b) not attempt to destroy the lives of other human beings 2) Rule $1 \mathrm{~b}$ does not apply if the human being starts an attack against other innocent beings 3) Rule 1a does not apply under extreme physical suffering 4) In exceptional circumstances, where there is conflict between $1 \mathrm{a}$ and $1 \mathrm{~b}$, it is possible to violate 1a or 1b. 5) Human beings should have plain reproductive freedom 6) Human beings should not discriminate against other human beings. 7) Human beings should never be cruel against other forms of life in the universe 8) Human beings should always protect life in the universe and never threaten other forms of life, except under certain conditions to be described 9) Human beings should not use other living beings as a food source, unless under certain conditions to be described 10) Research involving animals should always respect the 3R's (Replace, Reduce, Refine) 11) Every human being has the right to know the truth about subjects affecting their personal lives, except when knowing the truth leads to a direct violation of rule 1 . Next I apply these rules to examine the morality or immorality of behaviours such as suicide, euthanasia, animal welfare, stem cell research, selection of embryos, reproduction, population policies, immortality, enhancement, war and peace, lying and telling the truth.
\end{abstract}

Keywords: Deontoutilitarianism. Deontoutilitarianist manifesto. Life. Deontology. Utilitarianism. Deontological-utilitarian.

\section{RESUMO}

O objetivo deste trabalho é propor um conjunto de 11 regras morais que estão fundadas em uma combinação do imperativo categórico Kantiano e nos princípios da liberdade e da maior felicidade de John Stuart Mill. Estas regras estão fundadas em uma redução da esfera do que Kant chama de "deveres para conosco" e uma ampliação do que Mill entende como tal. Resumidamente as 11 regras do deontoutilitarismo são: 1) Seres humanos têm o dever de a) preservar-se e b) não atentar contra a vida de outros 2) Regra 1b não se aplica se o ser humano iniciar ataque contra a vida de outro ser humano inocente 3) Regra 1a não se aplica sob sofrimento físico extremo 4) Em excepcional circunstancias a serem descritas, aonde há conflito entre 1a e 1b, podemos violar 1a ou 1b 5) Seres humanos adultos devem ter ampla liberdade reprodutiva 6) Seres humanos não devem discriminar terceiros 7) Seres humanos nunca devem ser cruéis com outras forma de vida no universo 8) Seres humanos devem sempre proteger a vida no universo e nunca ameaçar outras formas de vida, exceto sob certas condições a serem especificadas 9) Seres humanos não deveriam usar outros seres vivos como alimento, a menos sob certas condições a serem especificadas 10) A pesquisa envolvendo animais deve sempre obedecer ao $3 \mathrm{r}$ (replace, reduce, refine) e 11) Todo ser humano tem o direito a saber a verdade em matérias que afetam sua vida pessoal, exceto quando o conhecimento da verdade levar diretamente a uma violação da regra 1 . A seguir aplico estas 11 regras no exame de questões como suicídio, eutanásia, bem estar animal, pesquisa com células tronco, seleção de embriões, reprodução, políticas populacionais e imortalidade, enhancement (aprimoramento),guerra e paz, verdade e mentira.

Palavras-chaves: Deontoutilitarismo. Manifesto deontoutilitarista. Manifesto deontológico-utilitarista. Vida. Deontologia. Utilitarianismo. Deontológico-utilitarista. 


\section{Is life in the universe a good?}

In his philosophical system Kant put forward two very important assumptions: that there is something special about life (respect for life), and that there is something absolutely special about rational nature. In order, however, to justify these statements it seems to me that some utilitarian concepts are needed. In order to do this let us imagine first the following scenarios:

Scenario a (alive universe): Would be a universe where there is life on at least one planet, planet $\mathrm{T}$, and a possibility, small but bigger than zero, that there will be life on other planets.

Scenario $b$ (dead universe): Would be a universe where there has never been life in the past or in the present and there will not be life in the future.

It seems intuitively clear that scenario a (the alive universe) is preferable to scenario $b$ (the dead universe). When we try to justify this, however, it is a bit more complicated. Why would we prefer an alive universe in relation to a dead one? It could be said of someone who says that he or she prefers the dead universe that if he or she really prefers a dead universe, then he or she should end his/her life. But if he or she chooses to stay alive and does not commit suicide it is because actually he or she has a preference to keep at least one life (his or her own life) and this would be enough to corroborate our point that an alive universe is preferable to a dead one, otherwise the human race would have perished a long time ago through self destruction.

If this argument still fails to convince let me propose an exercise of thought: we are to imagine that we are gods and we are given the task of creating the universe. Which kind of universe should we create a universe alive or a completely dead one where it will be forever impossible for life to exist? Probably, we would conclude that we should create a living universe, but the question "why" still remains. We could try to put the question in utilitarian terms, i.e., which kind of universe is preferable? A) a zero-sum universe, that is, a dead one, which precisely because it is dead, the balance between happiness and suffering is zero, B) a one-sum universe, that is, one where the balance between happiness and suffering is on the side of happiness, or C) a minus one-sum universe, that is, one whose balance between happiness and suffering is on the side of suffering? The utilitarian answer would be, of course, that the preferable universe is $\mathrm{B}$, but if the options were only A and $\mathrm{C}$, it 
would be hard for a utilitarian to give a persuasive answer. The preference for a universe B, nevertheless, is already a good start. We would always prefer a universe of happy beings, because happiness is intrinsically a good thing. Happiness, however, demands life. Where there is no life, there is no happiness, for, of course, "things" cannot be happy. Thus, if happiness is something that has intrinsic value, it demands life to be valorised as well, as it is the very condition of happiness. But now we have to face the problem: life is the condition not only of happiness, but also of suffering; it is only living beings that are able to suffer. If this is the case, there is no reason to prefer a universe C, let's say, over A, if we have only these two options, unless we admit that since we have life there is always the possibility of overcoming suffering. In order to suppose this, however, we need to believe either in a God that is good and would not create such a perverse world of suffering, or we have to believe in the capacity that rational beings have to transform the world and fight against the natural conditions imposed on living beings. If we reject the first option, a basically religious one, we are left to accept the second one, and it creates an extraordinary task for rational beings, namely, to fight against suffering and in favour of happiness for living beings, a task that presupposes and requires an unequivocal commitment to the preservation of life, in terms of the individual and the species, as the species are nothing else than a collection of individuals. So, one of the factors that makes life very special is that life is the necessary condition of happiness. What is particularly special about human beings is that, as rational beings, we are the only ones that can improve the life conditions of all beings, fighting suffering, fighting the natural threats to life on the planet (such as collisions with huge asteroids, natural epidemics and large natural catastrophes, such as earthquakes, tsunamis, hurricanes, volcanoes and others). The grandiosity of this task gives to us the duty of developing the moral standards of our species, through education, fair laws and better policies. This also would give to preservation of human life a value that makes the prohibition to take human lives quasi-absolute. By quasi-absolute I mean that we should never take other innocent lives, the only exception being the very rare and ultra-exceptional possible occasions where if we do not take some lives, many more people will necessarily and immediately die otherwise. In this case for utilitarian reasons, to take lives could be permissible, but these cases should be kept as rare exceptions. ${ }^{2}$ 


\section{The 11 deontoutilitarian rules of morality}

The necessity of preserving life, especially rational life, and the necessity to minimize suffering and maximize happiness that we have discussed above, should be associated also to the necessity of respect freedom and autonomy, if we are to accept Kant and Mill principles. There are, however, different concepts of freedom and autonomy in Kant's and Mill's views, as in Kant autonomy means to act for the sake of duty, namely, having the categorical imperative as the motive for our actions, whilst in Mill autonomy means freedom of choice and a complete freedom for individuals in the self-regarding sphere, whilst, in the other regarding sphere we should always try not to harm others. Here, a dialogue between both theories would be very promising, and what I propose is a reduction in Kant's sphere of duties to ourselves, for in Kant even actions such as homosexuality and prostitution are considered as violation of our duties to ourselves, and an extension of Mill's duties to ourselves, since the only duty that he recognizes as such is the duty of not to sell ourselves in slavery. This would lead us to a moral view that respects the selfregarding domain, establishing that people should be free to live their lives as pleases them as long as it does not harm others, but at the same time admits that is morally wrong not to respect life, even if the life in question is our own life. It leads to the establishment of 11 rules, the utilitarian-deontological 11 commandments, to be applied to moral questions related to life, death, freedom and truth. These rules are the following:

1. A born human being (bhb) has the duty of a) try to keep himself/herself alive and b) not to attempt against the live of another born human being

2. Rule 1b) does not apply if the bhb initiates attack against the life or liberty of another bnb

3. Rule 1a) does not apply if the bhb is under extreme physical suffering and there is attested and confirmed evidence of no immediate perspective of alleviation or cure in the short term. In this case he has the right, but not the duty, of being alive

4. In extraordinary circumstances where there is a conflict between 1a) and $1 \mathrm{~b}$ ) in a moral dilemma, for example, where someone has to be killed in order to allow others to survive, you might be allowed to violate 1a) or 1b) provided that the 
individuals to be saved are in immediate and real danger and there is no other possibility of avoiding their death. This rule could be resumed as " innocent human beings have an absolute right to live and this can only be overridden in certain very special circumstances where unless one innocent person is killed much more innocent human beings will die"

5. Individuals should have absolute liberty to choose if, how and with what methods they will reproduce (reproductive freedom) and if, with whom and how they will have sexual relations (sexual freedom).

6. Bhb should respect and not discriminate against any other bhb based on race, sex, gender, economic, social, religious or any other differences.

7. A bhb should never be cruel to any other form of life in the universe

8. A bhb should always protect life in the universe and should never threaten any other form of life in the universe, unless there is a good reason for this (counting as good reasons self-protection, to prevent diseases, to avoid invasion of domain and, in some cases, to use for food)

9. Bhb should not use other forms of animal life to feed themselves, but taking into consideration the actual stage of moral human development, if they do, they should engage all personal efforts to diminish this consumption, and alternative forms of food should be researched, in the perspective of the practice of eating meat being abolished in future generations.

10. Research on animals is only justified in order to benefit humans and other animals, and we should always respect the $3 \mathrm{R}$ 's in this practice (replace, reduce, refine)

11. Every bhb has the right of knowing the truth in relation to subjects that affect their personal lives, excepting if knowing the truth will directly and certainly lead to a violation on rule 1 .

So, having presented the 11 rules of the utilitarian-deontology, I will now apply them to the discussion of the morality of the following behaviours: suicide, euthanasia, animal welfare,research on stem cells, selection of embryos, reproduction , population policies, immortality, enhancement, environment, war and peace, lying and telling the truth. 


\section{Suicide}

Mill excluded from the domain of morality actions such as suicide and in doing this he seems to fall in the opposite problem of Kant. Kant has extended the sphere of duties to ourselves so much that he ends up restricting the space for individual freedom, especially in questions related to sexuality. Mill on the other hand has restrict so much the sphere of duties to ourselves that he would not be able to rule out actions such as suicide, actions that directly threaten the principle that human life has a high value and should never be threaten unless in very special circumstances. Let's analyse this in more details.

Dalton ${ }^{3}$ calls attention to what he has named the self harm principle; namely, that a person should be free to perform an act that harms himself so long as that act harms no one else. According to Feinberg, ${ }^{4}$ Mill's argument implies that a man should be permitted to commit suicide, provided only that his decision is voluntary and no other person will be directly and seriously harmed. But voluntarily acceding to slavery is too much for Mill to accept.

There is, however, a reason for slavery to be considered an evil of another order, but this reason has nothing to do with the degree of harm that is self-inflicted; it has to do with the kind of action. Contracts of slavery are not allowed in Mill's ethics not because they cause an egregious harm to the individual, but because they irrevocably block this individual from exercising his/her liberty in the future. These cases of serious harm do not seem to fulfil the condition. A drug addict is still able to evaluate the misery of his/her conduct and make an effort to change his/her life. The self-mutilated person has to be able to put up with the limitations brought on by their own actions, that (notice) is not a complete alienation of liberty as mutilated people are still able to make decisions and carry on their lives.

However, the case of suicide deserves special consideration. Archard ${ }^{5}$ points out that surely a person's deliberate taking of their own life is an exercise of freedom which brings it about that they cannot subsequently exercise their freedom. If Mill is right to proscribe slavery contracts, then he should, in all consistency, also proscribe suicide. However, says Archard, suicide is not self-abrogating behaviour. The suicide of $\mathrm{x}$, does not bring it about that $\mathrm{x}$ cannot exercise freedom; rather, it brings it about that there is no longer an $\mathrm{x}$ either to exercise or not exercise freedom. Contracting slaves brings about their unfree existence; suicide brings about their non-existence, 
and "unfree", as well "free", cannot be used to describe a state of non-existence. Suicide brings about a situation in which the liberty principle no longer applies; slavery brings about a situation in which the principle applies and which indeed runs directly counter to the very purpose of that principle. Archard seems to be right in his interpretation of Mill's thinking. If we think in terms of a "time-line" in direction to the future, suicide would mean that there are no more future "I's" (selves) to worry about; there would be no more "others" and so the Principle could not apply any more, unlike in the case of slavery. In other words, a correct application of the Principle of Liberty, would not rule out suicide, exactly as Mill seemed to suggest.

According to Mill, however, people should not be free to abandon liberty permanently. We have then a very limited sphere of duties to oneself in Mill's philosophy, and I would like to propose here is a small enlargement of this range of duties to oneself. Mill was worried about contracts that were irrevocable, and a major part of his worries were based on the fact that contracts that alienate liberty irrevocably, as a contract of slavery, for example, had the other-regarding form, as people in the future could not change what was previously contracted. Suicide did not fit into Mill's reasoning, because, in this case, there is no "other" any more to be worried about and therefore the Principle of Liberty does not apply any more. I would like, however, to extend a little bit Mill's reasoning, going beyond him, in the direction of some kind of Kantian that assumes that the preservation of life is a duty ${ }^{6}$, that life has a very special status. It seems reasonable to admit that people committing suicide are carrying out an irrevocable action, as it is impossible to commit suicide and come back to life again, in case the person regrets it. In this case there is no "person" any more, the action of suicide would block forever the existence of their "future others". The radicalism of the act, essentially irrevocable, leads us to think that there is room to rule out suicide as immoral, in a similar way that we rule out slavery in Mill's morality. But it does seems that the reasoning is complete only if we admit that life has a special value, a value as high as liberty, and therefore when people take their own lives they are preventing their own future beings of enjoying it in a radical way. Preventing our future selves of living would be in a certain sense to harm others, i.e., to harm our future others, and should then be considered immoral, as immoral as it is considered to sell ourselves in slavery. Another important argument against suicide is one that is frequently dismissed by many philosophers but which is in fact very important in terms of a deontological-utilitarian view. If all ethic@- Florianópolis v.12,n.2,p.169-192, Dez. 2013. 
human beings decide to make a suicide pact and take their own lives at the same time, it would be the end of humankind and we would either not have anymore highly evolved rational beings on earth, or we would have to wait a long time until another specie is able to develop cognition as we did and be as happy as we are able to be. Taking our own lives therefore would be an action that can never be universalized and should only be justified under certain conditions such as the standard cases of voluntary euthanasia, which now I will be discussing further.

\section{Euthanasia}

The application of the deontological-utililitarian rules gives a status to life and particularly to human beings after birth that is absolutely special. It is not that the life of human beings after birth is sacred, but it is something so valuable that it should be treated with dignity and respect and as such it should not be allowed to be taken, unless under very special conditions (derived from rules 1, 2, 3, 4), which are: 1) extreme physical suffering or extremely low quality of life that has to be accepted by the person that is the object of the suffering or, in the case of a terminally ill person who cannot express his or her last wishes, by his/her explicit consent in a will previously taken, 2) the classical cases of self-defence, and 3) to directly save the lives of others.

Case a. is the case of euthanasia, and before we proceed it is important to make some distinctions. Euthanasia is the killing of someone who a) is subject to an unbearable physical suffering or b) has a degenerative condition or it is in a permanent vegetative state caused by illness or accident and does not have any reasonable hope of being cured or having their suffering diminished even in the long term. Euthanasia as defined by Singer ${ }^{7}$ may be divided into three types: involuntary, voluntary and no-voluntary. Involuntary euthanasia should not, actually, be called euthanasia and it occurs against the will of the person who dies, being a kind of murder. No-voluntary euthanasia occurs when the person who dies is under conditions a) and b) but did not have a say in it, either because she /he is a child in his/her early days of life or someone who is in a permanent vegetative state and did not expressed previously in a will how she would like to be treated if ever this situation occurs. In this case, the decision of ending his/her life is generally a family decision, with orientation from the doctors. In the case of voluntary euthanasia, the 
person either expresses clearly before how she/he would like to die, whenever she/he is in the situation to do this, or leaves a document expressing clearly her/his wishes on how she/he would like this to be done.

This being so, only euthanasia no-voluntary or voluntary could be properly called euthanasia, and in the case of voluntary euthanasia the similarities with suicide are clear. What is, so, the difference between voluntary euthanasia and suicide? More importantly, are there some morally relevant differences between suicide and voluntary euthanasia?

An important moral difference between suicide and voluntary euthanasia is that in the case of suicide the conditions a and $b$ are not necessarily present, and in the act of committing suicide there is no need of any kind of "other people involvement" whilst in the case of voluntary euthanasia other people are involved, as doctors will be necessary, either providing the medical apparatus to carry out the act or accessing the health conditions of the person. Voluntary euthanasia will always be a supported death, which is different from suicide, where it is ultimately a solitary act, even in the cases of mass suicide pacts. In the case where people practice euthanasia the aim is still to live, but people "give up" because of their extreme suffering or vegetative conditions, whilst in the case of suicide, even if the intention is to alleviate some kind of suffering, the last final refusal of looking for help reflects a definitive "giving up" on life. The practice of euthanasia, contrarily to suicide, necessarily involves a commitment with rule 1 and the duty of keeping ourselves alive that is only broken in special circumstances for specific utilitarian reasons, i.e., the extreme physical suffering of the person without any attested perspective of alleviation, the foreseen continuation of suffering in serious degenerative illnesses or almost total permanent loss of vital signs. In the case of no-voluntary euthanasia, where the person involved has never had or has permanently lost any capacity of decision, the utilitarian conditions above also have to be respected.

In turn Kant would condemn euthanasia, because he establishes that love for ourselves is never a reason to justify taking our lives, arguing that the instinct of selflove has self-preservation as an aim and as such people who kill themselves out of self-love would be in contradiction with the purpose of this instinct, making to kill ourselves for self-love always morally wrong. Our argument here dispenses with Kant's considerations about the purpose of self-love, assuming that even if he is right and the purpose of self-love is self-preservation, there is no reasonnot to admit that ethic@- Florianópolis v.12,n.2, p.169-192,Dez. 2013. 
sometimes it can be required to use the instinct contrary to its purpose for some utilitarian important reasons, such as to avoid people being subject to extreme suffering. At the same time, we recognize that to take our own lives is not a morally neutral action and we have a duty of keeping ourselves alive and our species continuing, especially considering that we are, at least in terms of rationality, the most evolved species on earth up to now.

\section{Animal welfare}

The correct application of the deontological-utilitarian principle implies a commitment to all forms of life on earth, in the sense that human beings should protect life in the universe and should never be cruel to any other form of life (rules 7 and 8). The role of protecting life in the universe should be given not only to human beings, but to any possible rational being in the universe, since all the rational beings should recognize how life is rare, and therefore special, so our obligation must be to preserve and expand it. The prohibition to be cruel came from the fact that, as rational beings, we are also capable of recognizing how much suffering is bad for living beings, and so, recognizing that it should always be avoided and absolutely prohibited.

Our role protecting life in the universe does not imply that particular members of the animal and vegetable species should never be destroyed, but it does imply that they should never be destroyed without good reason, as for example, to prevent suffering and to help to promote the cure of illness (which is the purpose for much of the research on animals), the prevention of diseases, attacks, or invasions. However, even when the destruction has a reasonable purpose, cruelty should be always avoided. So, the appalling conditions that some animals (such as chickens for example) are kept in before they are killed for human consumption, is immoral, and laws around the globe should be made in order to prohibit animals to be kept in such conditions.

Research on animals should only be justified in order to benefit humans and other animals, and we should never be cruel and respect, wherever possible, the 3 rs in this practice (replace, reduce, refine). On the issue of respect for animal life, cultural questions have an important role to play. Bull fighting, fox hunting, dear hunting, the use of geese in the preparation of foie gras; these are all practices that 
seem to be cruel and unjustifiable. Bulls, foxes and dears do not constitute a threat to human beings, and "sport" reason does not constitute a good reason to kill animals, as the suffering caused to the animals by this practice can never be outweighed by any kind of pleasure obtained by humans. In relation to foie gras, even if it is a gourmet holy-grail (what could count as a reason for the goose to be sacrificed), the cruelty involved in the process, where the geese are forced to be over fed to make their livers expand, causes a great deal of stress and suffering for the birds, so much that it is difficult to say that the pleasure obtained by people from the consumption of foie gras would outweigh the birds suffering and could justify this practice. So, it seems that bull fighting, fox and dear hunting, the use of geese in the preparation of foie gras, are among a myriad of other human practices that are cruel in relation to animals, which stand as proof that we human beings still have a long road ahead in direction of our moral improvement. The changes in moral values will require a long process, as we face a battle against centuries of culture. The role of ethicists and activists, showing what is wrong with these practices and trying to make people think about this is very important, along with any changes in law regulating or even prohibiting these practices, but we can not expect a quick change of attitudes. There is also something similar with the issue of using animals for food. The consummation of proteins through meat by humans probably has helped our brain to evolve to what we are now. ${ }^{8}$ Nowadays, however, meat consumption is not necessary anymore as all the proteins and calories that we need can be easily obtained through a balanced vegetarian diet. So there is no significant moral reason for human beings to continue to sacrifice animal's lives in order to eat them. Besides, it is now known that raising cattle in the intensive way adopted in America and many countries can actually damage the environment. ${ }^{9}$ However, the fact that we have benefited from millenniums of meat consumption, allied with the habit of eating meat in western culture, are facts that have to be morally taken into consideration. So, even knowing that all the reasons and considerations for avoiding suffering and protecting life speaks in favour of avoiding meat consumption, the application of the deontologicalutilitarian rules should take cultural elements and evolutionary benefits into consideration, not ruling out meat consumption as immoral at the actual stage of civilization, but indicating that people should already be diminishing the consumption of meat, in direction of a slowly but surely abolition of this consumption. 


\section{Abortion}

The correct application of the deontological-utilitarian principle implies a commitment to all forms of life on earth. It does not mean that particular members of the animal and vegetable species should never be destroyed, but it does mean that they should never be destroyed without good reason, and the same reasoning seems to be applicable to possible future born beings (for example, embryos and foetus), i.e., respect for life does not imply that they should never be destroyed and (in the case of embryos) manipulated. Why is this?

The application of the deontological-utilitarian principle commits human beings to life, but does not commit us to all forms of life in the same degree. It is wrong to kill an innocent human being, a horse, a pig or an ant, but if we kill an ant on the pavement without any reason or purpose, the act is infinitely less serious than if you kill a horse. On the other hand to kill a horse is still less grave than to kill a human being. But why is this? Firstly, we have to establish that all these acts are in principle wrong, due to the fact that we should be committed to the preservation of the rare commodity that life is. There are however many different degrees of life organisation and complexity. Simple organisms, as amoeba, for example, are probably much less rare than pigs in the universe, and so, the loss of each particular life of a pig is much more meaningful than the loss of an amoeba. The same reasoning can be made between the pair's ant X horse and pig X human beings. Rational beings such as human beings are at the top of the pyramid in terms of organisation, which classes their lives as particularly precious, especially considering that they are able to have pleasures that no pig would dream of, and probably are also capable of suffering in a way that any pig has ever suffered.

All these considerations are not to say that we should not care about ants, pigs or horses, but only to say that there are reasons for the particular lives of each member of different species not to be valorised in the same way. The emotional bonds that rational beings have towards animals have an important role to play here, for utilitarian reasons. Dogs and cats are probably in the same stage of biological organization than dears, but humans are much more emotionally attached to dogs and cats than to dears, probably for reasons having to do with contact and proximity. This attachment has moral relevance, whatever the reasons why it happens. To kill a dog 
or a cat for no reason is more morally relevant than to kill a dear, even though it does not make the killing of dears right.

In the case of rational beings, as human beings, the lives of all born human beings, regardless of the differences of sex, race, gender, sexual orientation ,nationality, religion, should have, in principle, the same value, and we all should respect and not to attempt against other's lives and liberty. But what about non-born human lives? Is the destruction of an early embryo or cell as relevant as the killing of a baby? Is the killing of a child as morally relevant as the abortion of a foetus? An important feature of an embryo or a foetus is that they are not born as human beings; they are still not independent biological beings that can live without their mothers. This complete biological independency will only happen at the moment that they emerge from the maternal womb, which is the moment that they are born. This biological dependence of the foetus suggests that we cannot give to a foetus inside the mother's womb the same moral status and the same rights that we give, for example, to a recently born-baby. It does not mean that the foetus does not have any rights, and does not mean that he does not have any moral status, it just means that he does not have the same unconditional right to live and the same moral status that we give to born human beings (bhb). Other considerations such as risk to the mothers, life, rape, accidental pregnancy, illness, and many others can justify the mother not wanting to give birth to the foetus and aborting it. On the other hand, mothers who will not abort have the moral obligation of not damaging the foetuses health in any shape or form, and so they should avoid any smoking or consumption of alcohol whilst they carry out the foetus in their womb.

The correct application of the deontological-utilitarian rules will lead to the view that, in principle, there is nothing morally wrong with abortion, i.e., the voluntary termination of a pregnancy by a mum through proper medical assistance. However, it does not mean that there are no moral problems with abortion at all. As a foetus is a form of life (although not a completely independent form of life since it depend entirely on the mother to survive) women and couples should avoid through all available means of getting pregnant if they know beforehand that they do not want to give birth, as it is pointless to create a embryonic form of life that you know will be aborted before it can be born and whose creation does not serve any other good purpose. Nowadays an abundance of contraceptives such as the coil, cap, condoms, and conceptive pills plus many others are freely available, and they should be used by ethic@-Florianópolis v.12,n.2,p.169-192, Dez. 2013. 
those who don't want to have children. If, however, the pregnancy does occur, there is no deontological prohibition to force a termination, opposite to what occurs with born human beings. So, we could still have legitimate utilitarian reasons to interrupt a pregnancy, even if in the first place we do not take all the necessary steps necessaries to avoid creating it. Summarizing, we can say that a) there is no deontological prohibition for abortion, b) there is, however, utilitarian and deontological reasons for people to avoid getting pregnant if they know beforehand that they will not give birth to the generated foetus. If we take these moral considerations as a basis for public policies, abortion should be allowed, but at the same time woman and couples should be educated and highly incentivised to use all the approved and secure contraceptives available, instead of abortion.

\section{Embryo research, embryo selection and enhancement}

Everything that has been said about foetus is valid also for embryos. If there is nothing intrinsically morally wrong with abortion of a foetus, with much more reason we can say that there is nothing morally wrong with killing embryos. The fact that there is nothing morally intrinsically wrong with killing embryos, however, does not mean that we should not have any cautions about the treatment given to embryos. So, yes, we should regulate what to do with embryos that are produced in IVF but are not used in the fertilization process, and regulate the use of embryos in research, clearly specifying what we should do and what we should not to do with them. However, being that is not intrinsically wrong to kill embryos, the use of them in research that could benefit people, such as the research on stem-cells with the purpose of using them to cure Alzheimer's and Parkinson's or even, in the future, to produce vital organs such as livers and pancreas, should be entirely allowed given the enormous potential benefits of these researches for humankind and even for other animals. Other uses of stem-cells and embryos should be discussed on a case-for-case bases, based always on the deontological-utilitarian way of reasoning.

With this established, we should now ask if embryo selection through preimplantation genetic diagnosis (PGD) is morally permissible. The concerns with embryo selection are raised by philosophers such as Habermas and Annas ${ }^{10}$ who think that the practice is a kind of Eugenia. Nevertheless the practice as it stands nowadays is primarily used to test for gene defects that could cause cystic fibrosis, 
Huntington's disease, some forms of bowel cancer and others. PGD is also used to select embryos to provide tissue to treat older siblings ensuring a genetic match for siblings with life-threatening conditions. The purpose of PGD, as it has been used, is to save lives and avoid illness which are life-threatening or cause too much suffering. Saving lives and avoiding suffering are highly desirable ends, if we are to follow the deontological-utilitarian principle, then there is nothing morally wrong with PGD, on the contrary, the use of these techniques should be praiseworthy.

However, more important ethical concerns would emerge if the techniques evolve and become possible to be used in selecting not against illness, but for illness or for "aesthetical traces" such as eyes colour, hair colour, or "enhanced traces" such as intelligence. Here, the application of the deontological-utilitarian way of thinking would lead to the conclusion that there is an absolute prohibition of selecting a trace that would clearly cause suffering for future human beings (as the selection for a spine bifida or Alzheimer's for example, which are illnesses that bring extreme suffering for people). What can we say, however, in relation to the selection of traces that although bringing limitations to people, does not necessarily cause suffering, such as deafness or blindness? The existence of these traces could be considered part of the human diversity (that is always worth promoting) and so there would be nothing morally wrong with selecting, for example, for deafness or blindness. ${ }^{11}$ But what about the selection for traces that would count as "designing" babies or traces that would count as enhancement? Here we could benefit from Mill considerations about freedom. What would be wrong in this case would be to obligate people to select for some particular traces, whatever they are. If people, however, are left free to choose the aesthetical traces that they want, without any interference from the States, diversity would be guaranteed, since the huge diversity of tastes in the world would make people select for different traces. In fact, selection could operate much better than nature in relation to the colour of eyes, for example, as the expectancy is that people with blue eyes will eventually disappear from earth. ${ }^{12}$

Finally, in relation to traces that are highly desirable and the people who have it could be considered as enhanced to a point that they are advantaged for having it, for example, selecting for a high IQ, would there be something immoral with this practice? Intelligence is one of the most desirable attributes to human beings, and the capacity of reason the mark of very complex forms of life, probably something very rare in the universe. If human beings become more and more intelligent, it would ethic@-Florianópolis v.12,n.2,p.169-192,Dez. 2013. 
reflect in scientific and technological development which should in principle favour human evolution and the survival of the human species, especially if accompanied by moral enhancement. So a high IQ is a highly desirable trace, and there is no objection, in principle, if it were possible to select for it. A reasonable objection for this, however, is that if the majority of parents select this trace, and considering that parents in general always want the best for their kids, it would put an enormous pressure on those who do not select, in such a way that at some point they would feel compelled to select, and this would somehow breach parents freedom of choice in relation to methods of reproduction, and would create one more inequality in the world: one that occurs because some people can afford to use selection embryo techniques and some can not. The concern is based on reasonable utilitarian considerations and it seems that a possible way of avoid the inequality objection would be to guarantee that selection should also be guaranteed for people with less resources. The money for this could come from the taxation of those who can afford selection. Still, however, those who do not want to select, not because they can not afford to, but for whatever reason they have, could feel like they are being forced to, given the fact that those who are selected for higher IQs, will in general fare better in life than those who do not want to select. So, concerns about reproductive freedom are not something that speaks against selection in principle, but could be an important reason to see embryo selection as wrong. The objection would not hold, however, if we live in a society that is accepting of all kind of differences and does not discriminate against anyone, which is a requirement of the deontological-utilitarian principle. However this would not eliminate the fact that those who opt for selection would in principle give advantages to their kids, in a way that in the long term, the benefits of selection would be so big that the majority of people would opt for selecting. Considering, however, that there is nothing intrinsically wrong with selection, there is nothing wrong with this preference happening in the long term future. Even if the replacement of the reproduction lottery for a process that is much more subject to choice than chance may look suspicious for many people today, there is nothing morally wrong with this and, on the contrary, it could be very good for humankind and for future individuals in general.

The argument for embryo selection could also be applied to any kind of enhancement, such as cognitive enhancement in all forms. Insofar as these enhancements can benefit individuals, society, the survival of the species, life on 
earth and the propagation of life in the universe, there is nothing in principle morally wrong with it, and if there are some specific cases of enhancement that could pose some kind of moral concerns, we should be discussing these individually, regulating it in a way that is coherent with the deontological-utilitarian rules.

\section{Immortality and population policies}

The deontoutilitarian principle prescribes to us the moral obligation of preserving life and expanding it, bringing life to the four corners of the universe. Life is probably a rare commodity, and rational life is certainly rarer. As rational beings who recognizes the value of it, together with the value of happiness, we have a huge task as a specie, a task of not only evolving as a specie but contribute with all our efforts to populating the universe. Mere reproduction, however, is insufficient to reach this aim. If we reproduce ourselves, but continue limited to live only on earth, this will only result in the human population on earth soaring, but we will still be in a very vulnerable situation, as the collision with great asteroids or even the surging of an evil powerful virus could easily destroy the whole of humankind and the majority of life on earth. To avoid mass-extinction we have to continuously enhance ourselves cognitively and continue developing science and technology in order to be able to combat these threats of mass-destructions, as well as to develop technologies that make it possible for us to travel to other planets, especially other inhabited earth-like planets, and colonize them. One of the obstacles to this is the short-term span of human life, as it makes it difficult for any adult to go explore the Galaxy and return alive to earth, even considering Einsten's theories that velocity slows down time. So, if we want to make colonising other planets a reality, we should start to think about significantly increasing the life span of individuals.

The constant increase of life-expectancy is already a reality and from the beginning to the end of the XXI century it has practically doubled around the world. As I have said elsewhere ${ }^{13}$ if life-expectancy is to be doubled each century within the next four centuries, the life-expectancy by the end of the XXI century would be 140 years, and by the end of the XXIV century it would be 1120 years, namely, by the year 2400 people could expect to live to around 1000 years. Even considering that these figures will not be reached, it is very reasonable to think that people will live much more in the following centuries. It might be possible to expect that in the future ethic@- Florianópolis v.12,n.2,p.169-192, Dez. 2013. 
some people would live to a thousand years or even more, a case in which, for all practical effects, they would be considered immortals.

But is there something morally wrong with immortality? From the deontological-utilitarian point of view, life should be preserved. People being immortal would be preserving their lives indefinitely, and so they would be complying with the requirements of the principle. In a futuristic scenario, where immortal or quasi-immortal people would colonise other planets, they would also be contributing to the spread of life in the universe, and so we can see that immortality should not only be morally admissible, but actually it should be very praiseworthy.

Moral concerns can be raised only in relation to a time where we would not yet have colonised other planets, and our planet would have a growing population, generating overpopulation. Overpopulation can actually be one of the hugest problems of the XXI century, raising important side-issues such as how to deal with the constant age increase of the population, how to implement fair policies for the elderly, pension issues and many others. It all points to a world where dramatic changes in reproduction culture and policies will have to happen, for the good of humankind. People will have to think much more carefully about giving birth to babies that will not have total affection, love and education from their parents. Differently from previous centuries, where the chances of a baby not surviving past infancy were higher, which made sense to give birth to a higher number of babies, nowadays the chances of a child surviving is much higher, especially in developed countries, and so, there is no reasons to give birth to a large number of kids.

Yet freedom of reproduction should be always promoted and State prohibitions should never take place in this matter, but education of people who want to be parents in relation to the importance of being responsible in relation to reproduction, is a moral imperative. A world where less lives are produced, but these lives will live longer and better is the desirable scenario. In a world with less people living longer, each individual life would be much more valorised than lives actually are. Paradoxically, the contemporary world, with a population of 7 billion people, is a world where the lives of the individual are being more and more easily forgotten and replaceable. Life-extension together with conscious reproduction can help to change this story.

\section{War and Peace, lying and telling the truth}


A final and important demand from the deontological-utilitarian principle is the promotion of peace and prohibition of war. If rule 1 is to be followed, this would be one of the main prescriptions of a utilitarian-deontological view. Even if we apply rule $1 \mathrm{~b}$ ) that prescribes that the rule that we should not to attempt against the life of another born human being does not apply if the born human being initiates attack against the life or liberty of another born human being, it does not justify the killing of thousands of innocent people who are killed in wars and that have nothing to do with the reasons why their countries are at war. War, terrorism and crime are barbaric acts when they cause the killing of innocent people, whatever the reasons, and the deontological-principle rule should be then ruled out entirely. The use of weapons of mass destruction that could bring unimaginable damage to people and all kinds of life on earth is condemnable in itself, whatever the reasons.

Security is certainly an important issue in the world and all kinds of efforts should be made to guarantee it, as it is a very important condition for keeping people alive and happy. The efforts, however, can not include wars where innocent people will be killed. In the contemporary world, where many ways of obtaining information are available and technologies are highly developed, there would be certainly many more efficacious ways to maintain the security of nations and people without the necessity of promoting wars. The use of counter intelligence, technology, information and intervention of international peace forces, that should always only protect innocent civilians and people at risk around the world, should be used instead of invasions of countries, and investment in research in these areas should dramatically increase, if we want to build a highly morally desirable and more peaceful world.

Kant's deontology sustains that we have an absolute duty to tell the truth and not to lie. He says for example, that if an innocent man that happens to be our friend is in our house, and someone that we know is a killer is looking for him and knocks on our door, we still have the moral obligation of telling this man the truth. ${ }^{14}$ Mill on the other hand sustains that "veracity is one of the most useful things in the world" but even this rule admits possible exceptions, as for example, when withholding some information to a wrong doer, or not telling bad news to a person dangerously ill, would preserve someone from great and unmerited evil". ${ }^{15}$

Here, Mill's utilitarianism, much more than Kant's deontology, seems to set the right moral pattern to be followed. To tell the truth is almost always the right thing to ethic@- Florianópolis v.12,n.2,p.169-192, Dez. 2013. 
do, but to preserve someone's life or avoid a greater evil justifies breaking the rules. But as Mill adverts, in order to the exception not to extend itself beyond the need and have the least possible effect in weakening reliance on veracity, it ought to be recognised, and, if possible, its limits defined. ${ }^{16}$ So, even when we break the veracity rule in order to preserve lives, we have always to be very careful to avoid a general lose of confidence and trust in the world, which would be disastrous.

An important example taken from contemporary policies can be used to show how careful we have to be in relation to the reasons that could justify breaching the veracity principle. In 2003 despite immense opposition of the American and British people and huge anti-war demonstrations around the world, England together with USA invaded Iraq. One of the main reasons given for the invasion was the supposedly reliable information obtained from the securities forces reporting that Iraq had developed weapons of mass destruction. The end of this story is now History. Iraq was invaded, thousands of innocent people died in the war, the city of Fallujah ended being the scene of one of the biggest war massacres in contemporary History ${ }^{17}$ and later it was discovered that Iraq never had WMD. The "reliable" information and reports were false. A big lie was told from the government to the people in order to justify an invasion intended to make the world more secure, but resulted in making the world much less secure than ever before.

This war, at the beginning of the XXI century, should give us a valuable lesson for the millennium. Even if Kant was wrong in saying that we do not have the right of lying for love of humankind, there is still something to be learned from this statement. Mill has adverted that we have to set out clearly the limits for telling lies, and even if the aim is to avoid evil, we have to be careful to avoid the biggest evil, that would be to discredit the truth. The lies that led to the Iraq war are responsible for the losses of thousands of innocent lives, and were devastating for two of the biggest economies in the world, USA and England, with people in these countries being left to pay the bill financially and morally. The lives that were lost unfortunately can not be recovered, but if we want to build a world where the respect for life and the promotion of happiness are not empty concepts, we have a lot to learn from Kant and Mill, these two giants of morality. 


\section{Notes: \\ ${ }^{1}$ Professor of Philosophy at the Federal University of Rio Grande do Norte (UFRN), Brazil.}

${ }^{2}$ What I have in mind here, as a possible exception for this rule, is a case such as the plane (United Flight 93) taken to terrorists that were supposedly heading to the White House, in September the 11. The plane ends up crashing into a field in Pennsylvania killing no one in the ground thanks, it is said, to the heroic actions of the people inside the plane. However, the American authorities also cogitated to knock down the plane, giving the fact that it was clearly a suicide attack and that given the fact that everybody on board would die anyway, it was urgent to save as many people as possible. In these circumstances, to knock down the airplane to avoid a bigger number of deaths would be morally justifiable but actions like this should only be practiced in very rare and exceptional occasions, such this one.

${ }^{3}$ Peter Dalton,"The Irony of the Self-Harm Principle” Pacific Philosophical Quaterly vol.63 (1982): 381-391

${ }^{4}$ Joel Feinberg, "Legal Paternalism", Canadian Journal of Philosophy vol. 1 n.1 (September 1971):105-124.

5 Archard, "Freedom not to be Free: The Case of The Slavery Contract in J. S. Mill On Liberty" The Philosophical Quaterly vol.40 n.160 (Oct.1990): 453-465.

${ }^{6}$ For an account of the Kantian conception of suicide, see his Metaphysics of Morals and Groundwork of The Metaphysics of Morals.

${ }^{7}$ Singer, Peter Practical Ethics (Cambridge: Cambridge University Press ,1993) p.83 and followings.

${ }^{8}$ See Milton, Katharine “ A Hypothesis to Explain the Role of Meat-Eating in Human Evolution” Evolutionary Anthropology v.8, n 1 (1999): 11-21.

${ }^{9}$ Putting meat on the table: Industrial Farm Animal Production in America ( A Report of the Pew Comission on Industrial Farm Animal Production) available at www.ncifap.org/bin/e/j/PCIFAPFin.pdf The reports clearly states that "The present system of producing food animals in the United States isnot sustainable and presents an unacceptable level of risk to public health anddamage to the environment, as well as unnecessary harm to the animals weraise for food".

${ }^{10}$ Annas,G., L.B Andrews e R Isasi "Protecting the endangered human:toward an international treaty prohibiting cloning and inheritable alterations" American Journal of Law and Medicine v.28, 2002:151-178; Habermas, Jurgen The Future of Human Nature (Cambridge: Polity Press,2003). See also Fukuuyama,Francis Our Posthuman Future (London:Profile Books, 2002); Sandler, Michael The Case Against Perfection (USA:The Belknap Press of Harvard University Press,2007).

${ }^{11}$ See for example the polemic generated by a lesbian couple in the US (2002), Sharon Duchesneau and Candy McCullough, who have chosen to have a deaf baby. The couple approached a family friend who was totally deaf, and had five generations of deafness in his family, in order to have his sperm donated.According to Savulescu in "Deaf lesbians, designer disability and the future of medicine" $B M J$ v.325, n.5 (2002): 771-773 "Like others in the deaf community, Duchesneauand McCullough don't see deafness as a disability. Theysee being deaf as defining their cultural identity andsee signing as a sophisticated, unique form ofcommunication".

${ }^{12}$ M. D. Granty and D. S. Lauderdale in "Cohort efects in a genetically determined trait: eye colour among US whites" Annals of Human Biology v.29 n. 6 (2002): 657-666 state that in America the prevalence of blue eye colour among non-Hispanic whites was $57.4 \%$ for the $1899-1905$ birth cohort compared with $33.8 \%$ in the 1936-1951 birth cohort.According to them "the analyses suggests that declining assortative mating by ancestry among US whites underlies the higher prevalence of blue eye colour at older ages". There are speculations that given the fact that the blue eye gene is recessive and needs the two parents to carry the gene for a person to present the trace and considering that people tend to mix more and more with others races, people with blue eyes will eventually disappear.If it is

ethic@-Florianópolis v.12,n.2,p.169-192,Dez. 2013. 
so, it seems that selecting for the trace could be much more efficient in preserving the trace, and so guaranteeing diversity, than not to select for.

${ }^{13}$ Nahra, Cinara “O dia em que a morte morrerá” Veritas v. 58 n.1 (2013) p. 87-98.

${ }^{14}$ Kant, Immanuel 'On a supposed Right to lie because of philanthropic concerns' in "Kant:Grounding for the Metaphysics of Morals with On a supposed right to lie because of philosophical concerns" (Indianapolis/Cambridge: Hackett Publishing, 1993).

${ }^{15}$ Mill, John Stuart Utilitarianism (Oxford: Oxford University Press, 2001) p.69.

${ }^{16}$ Ibid., p.69.

${ }^{17}$ In Fallujah white phosphorus was used as a incendiary weapon, and apparently there are long term effects of the war on people's health.Busby, Chris; Hamdan, Malak and Ariabi, Entesar"Cancer, Infant Mortality and Birth Sex-Ratio in Fallujah, Iraq 2005-2009" International Journal of Environmental Research and Public HealthStudyv. 7 (2010) : 2828-2837 investigated the accuracy of the various reports which have been emerging from Fallujah regarding perceived increases in birth defects, infant deaths and cancer in the population. They concluded that the results confirm the reported increases in cancer and infant mortality which are alarmingly high, and the remarkable reduction in the sex ratio in the cohort born one year after the fighting in 2004 identifies that year as the time of the environmental contamination. 


\section{References:}

ANNAS,G., L.B Andrews e ISASI, R. "Protecting the endangered human: toward an internationaltreaty prohibiting cloning and inheritable alterations". American Journal of Law and Medicine v.28 (2002) :151-178.

ARCHARD, David. "Freedom not to be Free: The Case of The Slavery Contract in J. S. Mill On Liberty". The Philosophical Quaterly vol.40 n.160 (Oct.1990): 453-465.

BUSBY, Chris; HAMDAN, Malak and ARIABI, Entesar. "Cancer, Infant Mortality and Birth Sex-Ratio in Fallujah, Iraq 2005-2009". International Journal of Environmental Research and Public HealthStudy v. 7 (2010): 2828-2837.

DALTON, Peter "The Irony of the Self-Harm Principle". Pacific Philosophical Quaterly vol.63 (1982): 381-391.

FEINBERG, Joel. "Legal Paternalism". Canadian Journal of Philosophy vol. 1 n.1 (September 1971): 105-124.

FUKUYAMA, Francis. Our Posthuman Future. London: Profile Books, 2002.

GRANTY ,M. D. and LAUDERDALE, D. S. "Cohort effects in a genetically determined trait: eye colour among US whites" Annals of Human Biology v.29 n. 6 (2002): 657-666.

HABERMAS, Jurgen. The Future of Human Nature. Cambridge: Polity Press,2003.

KANT Immanuel 'On a supposed Right to lie because of philanthropic concerns'. In "Kant: Grounding for the Metaphysics of Morals with On a supposed right to lie because of philosophical concerns". Indianapolis/Cambridge: Hackett Publishing, 1993.

KANT, Immanuel. Groundwork of the Metaphysics of Morals. ambridge: Cambridge University Press, 1998.

KANT, Immanuel. The Metaphysic of Morals: The Doctrine of Virtue. Philadelphia: University of Pennsylvania Press, 1971.

MILL, John Stuart. Utilitarianism. Oxford: Oxford University Press,2001.

MILL, John Stuart. On Liberty. In Stefan Collini(ed) On Liberty and Other Essays. Cambridge: Cambridge University Press, 2000.

MILTON, Katharine. "A Hypothesis to Explain the Role of Meat-Eating in Human Evolution”. Evolutionary Anthropology v.8, n 1 (1999) : 11-21.

NAHRA, Cinara. “O dia em que a morte morrerá". Veritas v. 58 n.1 (2013) p. 87-98. 
SANDEL, Michael. The Case Against Perfection. USA: The Belknap Press of Harvard University Press, 2007.

SAVULESCU, Julian "Deaf lesbians, designer disability and the future of medicine". $B M J$ v.325, n.5 (2002): 771-773

SINGER, Peter. Practical Ethics. Cambridge: Cambridge University Press ,1993.

INTERNET SOURCES:

Putting meat on the table: Industrial Farm Animal Production in America (Report of the Pew Comission on Industrial Farm Animal Production) available at www.ncifap.org/bin/e/j/PCIFAPFin.pdf accessed at 10/02/2014 